\title{
TRABALHO RURAL, REPRESENTAÇÃO CLASSISTA E LUTAS POR DIREITOS NA PRODUÇÃO DE MAÇÃS EM VACARIA-RS ${ }^{1}$
}

\author{
RURAL WORK, CLASS REPRESENTATION AND STRUGGLES FOR RIGHTS IN THE \\ APPLES PRODUCTION IN VACARIA-RS, BRAZIL
}

\author{
Nadine Gerhardt Lermen ${ }^{2}$ \\ Everton Picolotto ${ }^{3}$
}

\section{RESUMO}

O município de Vacaria-RS é o maior produtor individual de maçãs do Brasil, com uma produção em grande escala, altamente tecnificada e voltada para a exportação. Em contrapartida à eficiência de setores como esse, os trabalhadores rurais brasileiros vivem uma persistente situação de vulnerabilidade. Nesse contexto, temos como objetivo analisar o processo de construção dos direitos trabalhistas dos trabalhadores rurais de Vacaria-RS por meio da atuação de instituições como o Sindicato de Trabalhadores Rurais e de órgãos fiscalizadores do Estado e avaliar os efeitos da Reforma Trabalhista de 2017 sobre essa regulação local constituída. Para tanto, fizemos uso de entrevistas, observações diretas e análise documental e de dados secundários dos Censos Agropecuários, CAGED, IPEA e DIEESE. Assim, constatamos que a atuação conjunta dessas instituições constituiu uma rede de proteção para os trabalhadores rurais locais e que a Reforma Trabalhista de 2017 procurou esvaziar essas instituições e esses direitos.

Palavras-chave: cadeia produtiva da maçã, assalariamento rural, relações trabalhistas, Reforma Trabalhista, sindicatos rurais.

\begin{abstract}
Vacaria-RS is the largest individual producer of apples in Brazil and this production is in large scale, highly technical and export oriented. The modernity of sectors like this contrasts with the persistent vulnerability experienced by brazilian rural workers, despite the guarantees of labor legislation. In this context, the objective of this work is to analyze the process of construction of labor rights of the rural workers in Vacaria-RS with the help of work-related institutions and evaluate the effects of the Labor Reform of 2017 on this local standard of work regulation. For this, we used interviews, direct observations and analysis of documents and secondary data from the Census of Agriculture, CAGED, IPEA and DIEESE. Thus, we found that the joint action of these institutions constituted a protection network for local rural workers and that the Labor Reform of 2017 pursued to empty these institutions and these rights.
\end{abstract}

Keywords: apple production chain, rural wages, labor relations, labor reform, rural unions.

1 O artigo resulta de discussões realizadas no âmbito da dissertação de Mestrado intitulada "A vida por trás dos galhos das macieiras: (o)posições sociais e representação classista na cadeia produtiva da maçã em Vacaria-RS”, da primeira autora do projeto de pesquisa "Reconfigurações no sindicalismo rural: agricultores familiares e assalariados rurais em um cenário de disputas", coordenado por Everton Picolotto e financiado pelo CNPq.

2 Mestra em Ciências Sociais pela Universidade Federal de Santa Maria (UFSM). E-mail: nadineg.lermen@ gmail.com. ORCID: https://orcid.org/0000-0001-9644-7963

3 Professor do Departamento de Ciências Sociais e dos Programas de Pós-Graduação em Ciências Sociais e Extensão Rural da Universidade Federal de Santa Maria (UFSM). Bolsista de Produtividade em Pesquisa do CNPq. E-mail: everton.picolotto@ufsm.br. ORCID: https://orcid.org/0000-0003-4199-5553 
JEL Classification: J Economia Demográfica e do Trabalho; J5 Relações trabalhistas, sindicatos e negociação coletiva

JEL Classification: J Labor and Demographic Economics; J5 Labor-Management Relations, Trade Unions, and Collective Bargaining

\section{INTRODUÇÃO}

Um dos pilares fundamentais da constituição das sociedades modernas se deu com o estabelecimento da cidadania à condição de trabalhador e trabalhadora. Especialmente no pós-Segunda Guerra Mundial, foi concebido um sistema de regulação pública do trabalho e de proteção social, consolidado na legislação trabalhista na maioria dos países desenvolvidos e em desenvolvimento. Essa melhora do status de dignidade do trabalho foi alcançada por meio de décadas de lutas dos trabalhadores para transformar trabalhos em empregos, com direitos e dignidade, garantidos pelo Estado e legitimados socialmente. Dentre os principais mecanismos que garantem essa proteção estão o Direito do Trabalho e a Seguridade Social com seus três pilares: saúde, previdência e assistência social (CASTEL, 1998; KREIN, 2018).

A instituição desses mecanismos está baseada na solidariedade, gera coesão social e legitima as instituições de representação classistas, como os sindicatos. No entanto, o advento do neoliberalismo ${ }^{4}$ e do padrão de acumulação flexível têm promovido alterações nessa rede de proteção, buscando desregulamentar o trabalho e gerar um novo padrão de regulação social, individualizado e caracterizado pela resolução privada dos conflitos e não mais com a intermediação dos sindicatos e do Estado. Esse novo padrão tem resultado no aumento do desemprego, no enfraquecimento dos contratos de trabalho permanentes, na flexibilização e precarização dos empregos, na redução do poder de negociação coletiva conduzida pelos sindicatos, entre outros (ADASCALITEI; MORANO, 2016; BIAVASCHI; TEIXEIRA, 2018; KREIN, 2018; GALVÃO; TEIXEIRA, 2018; LÚCIO, 2019).

Esse embate entre dois modelos de regulação do trabalho - um com empregos estáveis e com a regulamentação pública e outro com empregos e contratos flexíveis e regulamentação privada - pode ser compreendido nos termos de uma disputa de ideias-força no campo político-econômico, que são os princípios que determinam a visão e a divisão do mundo social (BOURDIEU, 1989). Essa disputa envolve uma série de agentes sociais, como governos, empresas e sindicatos, que mobilizam capitais, discursos e indivíduos para alcançar melhores posições sociais e/ou se consolidarem socialmente e para que suas ideias-força se tornem hegemônicas. Essa disputa se torna ainda mais complexa em sociedades como a brasileira, marcada por grandes desigualdades sociais e por certa depreciação das classes subalternas pelas elites, o que teve origem no sistema escravocrata (SOUZA, 2018). Essa depreciação dos trabalhadores foi uma das razões pelas quais a conquista dos direitos trabalhistas e de um sistema de proteção social pelos trabalhadores brasileiros foi ainda mais desafiadora que em outros países, sendo alcançada de forma universal apenas com a Constituição de 1988, após décadas de luta de trabalhadores urbanos e rurais.

\footnotetext{
4 Por "neoliberalismo" se entende o movimento político e teórico de contraposição às concepções políticas e econômicas baseadas no keynesianismo e na intervenção do Estado na economia, predominantes no pós-Segunda Guerra. Como corrente de pensamento, fundamenta-se na ideia de que a sociedade se assenta na liberdade dos indivíduos e no funcionamento dos mercados, e como movimento político desdobrou-se "na formulação de um conjunto de políticas e de redefinições do papel do Estado, na perspectiva de construir uma sociedade autorregulável pelo mercado" (KREIN 2011, p. 245). Para essa corrente, a excessiva regulação do Estado e o "poder excessivo e nefasto dos sindicatos" (sic) seriam responsáveis pela perda do dinamismo econômico (ANDERSON, 1996).
} 
Os trabalhadores urbanos conquistaram seus direitos trabalhistas com o estabelecimento da Consolidação das Leis do Trabalho (CLT), reunião da legislação trabalhista promulgada em 1. ${ }^{\circ}$ de maio de 1943. Os trabalhadores rurais, por sua vez, passaram a contar com direitos trabalhistas e sindicais apenas na década de 1960, quando da aprovação do Estatuto do Trabalhador Rural (Lei n. ${ }^{\circ} 4.214$, de 2 de março de 1963) e seus direitos previdenciários só foram assegurados, de forma parcial, na década de 1970, de modo que apenas o chefe de família tinha direito à aposentadoria, que correspondia a meio salário mínimo (LAMARÃO E MEDEIROS, 2001; DELGADO; SCHWAEZER, 2000).

O sindicalismo rural brasileiro também foi regulamentado na década de 1960 e estruturado na forma de representação paralela entre patrões e trabalhadores. A representação dos trabalhadores rurais foi organizada nos Sindicatos dos Trabalhadores Rurais (STRs) no nível municipal, em federações estaduais e em uma Confederação Nacional dos Trabalhadores na Agricultura (Contag). Nessa estrutura, toda a diversidade de grupos sociais e de situações de trabalho rural foi enquadrada na categoria trabalhador rural, sejam eles assalariados, sejam pequenos proprietários, arrendatários, posseiros, entre outros. Como órgãos de colaboração com o Estado, os sindicatos receberam o "fardo" da operacionalização dos serviços assistenciais oferecidos para os trabalhadores rurais (especialmente saúde e previdência), mas também souberam se apropriar da execução desses serviços para consolidar sua estrutura e a identidade classista de trabalhador rural (PALMEIRA, 1985; MEDEIROS, 1989; 2010; NOVAES, 1997; PICOLOTTO, 2011).

O processo de democratização da sociedade brasileira ao longo dos anos 1980, bem como a pressão e as conquistas dos movimentos sociais na Constituição de 1988 favoreceram o fortalecimento da sociedade civil frente ao Estado e a ampliação da regulação e cobertura pública da proteção social. Na representação sindical, o Estado perdeu boa parte do controle que exercia sobre as organizações sindicais, e estas receberam maior possibilidade de atuação livre e autônoma em defesa de suas bases e pautas. Na previdência social ocorreu a "inclusão dos trabalhadores rurais e dos segurados em regime de produção familiar, chamados de segurados especiais, no plano geral de benefícios normal do Regime Geral de Previdência Social" (DELGADO; SCHWARZER, 2000, p. 196). O benefício passou de meio para um salário mínimo; as mulheres rurais passaram a ter acesso ao benefício; a idade para requerer o benefício ficou estabelecida em 55 anos para as mulheres e 60 anos para os homens (medidos pelo tempo de trabalho rural exercido e não pelo tempo de contribuição, como ocorre para os trabalhadores urbanos). Os direitos aos serviços de saúde também foram universalizados com o Sistema Único de Saúde (SUS), estabelecido pela nova Constituição (PICOLOTTO, 2011; 2018).

Apesar dessa universalização do sistema de previdência social e dos direitos trabalhistas e sindicais, grande parte dos trabalhadores rurais brasileiros ainda se encontra em situação de vulnerabilidade social, sendo os assalariados rurais um dos grupos sociais mais distantes da proteção social. Os dados de um estudo do Dieese (2014) mostram que, em 2013, dos 4.059.507 assalariados rurais brasileiros, 59,42\% trabalhavam informalmente, ou seja, sem as garantias dos direitos trabalhistas básicos, $56,4 \%$ não contribuíam com a previdência social e $85,4 \%$ não tinham filiação sindical, além de constituírem um grupo social caracterizado pela baixa escolaridade e renda.

Essa realidade contrasta profundamente com a modernidade dos setores nos quais esses trabalhadores são empregados, como é o caso da fruticultura, que emprega um grande contingente de trabalhadores em diversos estados, seja para a produção de laranjas em São Paulo, seja de manga e uva na Bahia, seja de maçãs em Santa Catarina e no Rio Grande do 
Sul. De modo geral, a produção dessas frutas faz parte de um setor de ponta do chamado agronegócio - caracterizado pela produção em grande escala, altamente tecnificada e voltada para a exportação - e está inserida nas cadeias globais de produção e comercialização de produtos primários. Para Mendonça (2013), o agronegócio é um modelo de industrialização da agricultura internacionalizado, no qual o capital incorpora todos os elos da cadeia produtiva, o que é viabilizado pelo capital financeiro e pela alavancagem estatal. Entre as características desse modelo estão a territorialização do capital e a oligopolização do espaço agrícola, fatores que agravam as desigualdades sociais e territoriais do país (ELIAS, 2006). E uma das consequências desse modelo é a prevalência de um mercado de trabalho vulnerável, marcado pela sazonalidade e pela precarização das condições de trabalho (BEZERRA; ELIAS, 2011).

Essas contradições também se fazem presentes no município de Vacaria-RS, que é o maior produtor individual de maçãs do país ${ }^{5}$. As grandes empresas produzem maçãs de alta qualidade para exportação por meio do trabalho de um grande contingente de trabalhadores assalariados, permanentes e temporários. De acordo com dados do Censo Agropecuário de 2017, no município de Vacaria havia 18.792 assalariados rurais, dos quais 4.781 eram permanentes e 11.890 eram temporários. Esse volume de trabalhadores cresce muito nos meses de janeiro a abril, quando ocorre a colheita das maçãs. Segundo dados do Cadastro Geral de Empregados e Desempregados (Caged), em janeiro de 2019 o município de Vacaria, que é um município de médio porte, teve o maior saldo de criação de empregos formais em todo o país, com 5.223 novos empregos gerados, seguido de Dourados-MS, com 4.441 novas vagas, Curitiba-PR, com 3.534, e São Paulo-SP, com 3.434 (BRASIL, 2020). Ao longo dos anos, esses trabalhadores se depararam com condições precárias de trabalho, mas essas vêm sendo atenuadas por meio da atuação conjunta e de esforços de diversas instituições, como o Sindicato dos Trabalhadores Rurais (STR) e o Ministério Público do Trabalho (MPT).

Com base nesse contexto, o objetivo do presente artigo é analisar o processo de construção de uma regulamentação dos direitos trabalhistas dos trabalhadores rurais de Vacaria nas últimas décadas, por meio da atuação local de instituições como o Sindicato dos Trabalhadores Rurais e de órgãos fiscalizadores do Estado, e avaliar os efeitos da Reforma Trabalhista de 2017 sobre esse padrão local de regulação do trabalho rural. Para alcançar o objetivo proposto, foram coletados dados primários e secundários. Os primários foram coletados durante o trabalho de campo realizado em Vacaria. Para isso, foram realizadas quatro visitas até o local de pesquisa e todas duraram em torno de cinco dias, sendo a primeira realizada em fevereiro de 2018, a segunda em junho de 2018, a terceira em novembro de 2018 e a quarta em setembro de 2019. Ao longo do trabalho de campo foram coletados documentos, realizadas entrevistas, conversas informais e observações diretas.

Foi realizada a análise documental das reportagens do jornal local Correio Vacariense, fundado em 1974, que realiza edições semanais e cujo acervo impresso está disponível na Biblioteca Pública Municipal. Foram consultados os jornais desde a edição 397, de 10/05/1983, até a edição 1.681, de 14/05/2003. Outra importante fonte documental foram as convenções coletivas de trabalho (1994-2019), as quais foram gentilmente disponibilizadas pelo STR. Também analisamos algumas reportagens do jornal Pioneiro, de Caxias do Sul-RS, e do jornal Zero Hora, de Porto Alegre-RS, que se referiam aos pomares de maçãs de Vacaria.

\footnotetext{
5 Segundo dados do Censo Agropecuário de 2017, o estado de Santa Catarina é o maior produtor de maçãs, com 550.839 toneladas produzidas, enquanto o Rio Grande do Sul é o segundo, com 539.559 toneladas, e a produção desses dois estados representa 96,7\% da produção nacional. Já o município de Vacaria, no nordeste do Rio Grande do Sul, é o maior produtor individual, com uma produção de 279.327 toneladas, o que corresponde a $24,7 \%$ da produção nacional (IBGE, 2019).
} 
Outra técnica de pesquisa utilizada foi a realização de entrevistas semiestruturadas. Foram realizadas quatro entrevistas, duas com uma liderança sindical dos trabalhadores rurais, em 26/02/2018 e 11/09/2019, uma com uma liderança sindical patronal e uma com um funcionário da Secretaria Municipal da Agricultura e Meio Ambiente, ambas no dia 25/06/2018. Além dessas entrevistas, foram realizadas diversas conversas informais com: 1) seis trabalhadores assalariados das centrais de classificação das maçãs, sendo três homens e três mulheres, no próprio sindicato dos trabalhadores; 2) duas agricultoras familiares, também no sindicato dos trabalhadores; 3 ) várias conversas, em diferentes momentos, com três lideranças sindicais dos trabalhadores rurais; 4) um juiz do trabalho na Vara do Trabalho de Vacaria, 5) um funcionário da Secretaria de Desenvolvimento, Tecnologia, Trabalho e Turismo na sede da secretaria; 6) dois funcionários da Biblioteca Pública Municipal, na própria biblioteca; 7) dois empresários das Ceasas de São Paulo e da Bahia que visitavam as empresas produtoras de maçãs em Vacaria e 8) um funcionário de uma empresa terceirizada que é responsável pelas vendas de empresas produtoras de maçãs. Já as tentativas de realizar entrevistas e visitas nas empresas não foram bem-sucedidas e, como não foi possível o deslocamento até Vacaria nos meses de colheita da maçã em 2019, não se pôde coletar dados diretamente com os trabalhadores temporários.

Já os dados secundários analisados são oficiais, extraídos dos Censos Agropecuários de 2006 e 2017, do Cadastro Geral de Empregados e Desempregados (Caged), vinculado ao Ministério da Economia, do Instituto de Pesquisa Econômica Aplicada (Ipea) e do Departamento Intersindical de Estatística e Estudos Socioeconômicos (Dieese).

\section{A CADEIA PRODUTIVA DA MAÇÃ E O TRABALHO RURAL NO MUNICÍPIO DE VACARIA}

\subsection{A formação da cadeia produtiva da maçã}

Desde sua origem, no início do século XVIII, o município de Vacaria teve nas atividades agropecuárias a base de sua economia. Historicamente, a criação de gado foi a principal atividade desenvolvida no município, e as grandes fazendas foram o centro dinâmico da economia tradicional (BORGES, 2001; PINOTTI, 2011). Esse foi o panorama dominante até meados do século XX, quando as mudanças decorrentes do processo de modernização da sociedade brasileira evidenciaram os limites desse modelo, levando a um processo de recessão econômica, que teve reflexos no campo político local, até então dominado pelas elites tradicionais, ligadas aos fazendeiros descendentes de portugueses e à pecuária. No começo da década de 1970, Marcos Palombini e Enore Angelo Mezzari, um dentista e um bancário, descendentes de famílias imigrantes italianas ${ }^{6}$, que não tinham ligações com as elites locais, foram eleitos prefeito e vice-prefeito do município, por meio do capital político acumulado no processo de criação de uma cooperativa de produtores de leite no município. Esse reconhecimento se deu, especialmente, entre os produtores de base familiar e descendentes de imigrantes do município. E foi nesse novo governo que houve o desenvolvimento de um projeto de dinamização da economia

\footnotetext{
${ }^{6}$ Desde o segundo quartel do século XIX, foram estabelecidas em diversas áreas do Rio Grande do Sul e dos demais estados da região Sul colônias com imigrantes alemães, italianos e de outras nacionalidades europeias. Isso ocorreu também no município de Vacaria, que recebeu, em maior número, imigrantes italianos, anteriormente estabelecidos na região de Caxias do Sul, e que acabaram se estabelecendo e formando pequenas comunidades nas áreas rurais de Vacaria. Segundo Seyferth (2000, n.p.), estes imigrantes diversificaram a economia local e formaram uma estrutura agrária baseada na pequena propriedade familiar. "Juntamente com outros grupos de imigrantes, principalmente italianos e poloneses, formaram um campesinato cuja característica mais marcante foi produzida pela fixação (obrigatória) no lote colonial - sua unidade econômica básica".
} 
local por meio da pomicultura comercial, com base no modelo que vinha sendo implantado em Fraiburgo-SC e apresentando resultados positivos. Desse modo, em 1973, uma comitiva formada por integrantes da prefeitura e alguns produtores rurais de base familiar do município foram à Fraiburgo conhecer a atividade. Após avaliação de que a atividade seria viável e com o apoio da prefeitura, esses produtores plantaram os primeiros pomares do município, ainda em 1973 (CORREIO VACARIENSE, 17/02/1989, s/p.).

Ao longo da década de 1980, com base nos bons resultados alcançados pelos pioneiros da produção de maçã no município, a atividade foi se expandindo, desde o número de produtores até a quantidade produzida, nas atividades ligadas aos insumos e ao transporte e na indústria de transformação. Entretanto, essa expansão não foi bem vista por todos os agentes locais. As elites tradicionais, ligadas à pecuária, foram contrárias ao projeto da pomicultura, associado à figura do prefeito Palombini. Com os bons resultados alcançados pelo setor, o prestígio de Palombini cresceu. Assim, ocorreu uma disputa política e econômica entre o setor econômico tradicional, ligado aos fazendeiros descendentes de portugueses e às elites políticas tradicionais, e o setor em ascensão, ligado aos descendentes de imigrantes italianos e seus representantes políticos (LERMEN, 2020). Essa disputa entre projetos econômicos envolveu ideias-força distintas, nos termos de Bourdieu (1989), que colocaram em questão as posições sociais dos agentes e sua hegemonia tanto no campo econômico quanto no campo político.

Com base na contínua expansão do setor, empresários consolidados em outros setores econômicos também passaram a investir na produção de maçãs e na cadeia produtiva emergente, em um processo de reconversão de capital econômico, ou seja, transferência de capital econômico e social, nos termos de Bourdieu (1989), de um setor para outro. Simultaneamente, ocorria o processo nacional de modernização agropecuária, intensificado a partir do final da década de 1960. Essa modernização foi resultado de uma política cujo principal instrumento foi o crédito agrícola, que resultou na incorporação de insumos modernos, no aumento da tecnificação e da mecanização, em ganhos de produtividade e na integração com amplos circuitos de comercialização, favorecendo os grandes produtores rurais e agentes de outras áreas econômicas dispostos em investir seu capital em atividades agrícolas subsidiadas e altamente lucrativas (PALMEIRA, 1999; SILVA, 1982; HEREDIA; PALMEIRA; LEITE, 2010).

Esses processos estimularam a concentração ao longo dessa cadeia produtiva. Grandes empresas foram então se consolidando no setor, passando a dominar a produção agrícola e de insumos, bem como os processos de classificação e industrialização das maçãs. Com isso, os produtores de base familiar, pioneiros na pomicultura do município, foram perdendo espaço, uma vez que não tiveram condições de competir com essas grandes empresas. Com isso, muitos desses pequenos produtores acabaram se voltando para a produção de outras culturas permanentes, como de uva e amora, que exigem menos investimento e tecnificação e cujos custos de produção são menores. Essa tendência se consolidou ao longo do tempo e, de acordo com os dados do Censo Agropecuário de 2017, enquanto 82\% dos produtores de maçãs de Vacaria se enquadravam na agricultura não familiar, $83,3 \%$ dos produtores de amora e $80,7 \%$ dos produtores de uva do município eram agricultores familiares (IBGE, 2019).

A concentração da produção de maçãs entre grandes empresas teve mais um impulso e foi acentuada após a abertura da economia brasileira no começo da década de 1990 e do processo de reestruturação produtiva do setor, que ocorreu ao longo da década de 1990 e no começo dos anos 2000. Com esses processos, as maiores empresas do setor deram um salto tecnológico e de produtividade. Em relação à face tecnológica da reestruturação produtiva, as árvores dos antigos pomares foram erradicadas e substituídas por variedades mais produtivas; foi adotado o plantio em alta densidade de mudas importadas; o know-how dos principais centros de fruticultura do 
mundo passou a ser incorporado e modernos equipamentos para fertirrigação, classificação e estocagem das maçãs foram importados (CORREIO VACARIENSE, 16/07/1992, s/p.; 03/10/1992, p. 7; 27/04/1996, s/p.; 01/03/1997, p. 18; 20/03/1998, p. 16).

Esses grandes investimentos tiveram como objetivo alcançar qualidade e competitividade para se inserir em mercados consumidores mais exigentes, como o europeu, que prefere produtos de qualidade superior e paga mais por isso. Essa estratégia se tornou viável porque essas exportações geram uma taxa de lucro maior do que a alcançada no mercado interno, caracterizado pelo menor poder aquisitivo dos consumidores. Tais estratégia e investimentos possibilitaram a consolidação e a hegemonia das empresas maiores no setor, enquanto os produtores de base familiar e as empresas menores ficaram em posições inferiores, perdendo em competitividade, tornando-se menos viáveis e, no caso das empresas pequenas e médias, passando a ser incorporadas pelas líderes do setor em processos de fusões e aquisições. Por meio desses processos, a produção vem se concentrando e, em 2017, dos 95 produtores de maçãs do município, 78 eram da agricultura não familiar (patronal), cinco deles com áreas de pomares entre 1.000 e 2.500 hectares (IBGE, 2019), sendo duas grandes empresas as líderes do setor no município.

\subsection{Atividades produtivas e a força de trabalho}

As atividades desenvolvidas ao longo da cadeia produtiva da maçã são: 1) produção de insumos, como adubos, equipamentos e máquinas; 2) produção agrícola, dividida em atividades como o plantio, o raleio e a poda das macieiras, a colheita das frutas e seu transporte; 3) operações relativas à indústria, que se subdivide entre as atividades do packing-house, que são a estocagem, a classificação e a embalagem das maçãs que serão consumidas in natura e as atividades da indústria de processamento, nas quais as maçãs são transformadas em matéria-prima para a produção de sucos, geleias, doces e vinagres; 4) transporte e distribuição das maçãs in natura e processadas para o atacado e varejo, até elas chegarem ao consumidor final, que é o último elo da cadeia produtiva. Todos esses setores promovem trocas de fluxos materiais e de capital e todos os processos são influenciados pelos ambientes organizacional (legislação, normas, regimentos, tradições e políticas econômicas) e institucional (institutos de pesquisa, bancos, associações de produtores, cooperativas e sindicatos) (RECH; CARIO; AUGUSTO, 2014). As atividades que demandam número maior de trabalhadores e que geram a maior parcela dos empregos do setor no município são aquelas relacionadas à produção agrícola e à indústria.

A implantação e a ampliação da pomicultura e a posterior consolidação da cadeia produtiva da maçã alterou significativamente o mercado de trabalho no município. Como a fruticultura emprega um grande número de trabalhadores, a implantação da atividade foi muito importante para resolver a questão do desemprego local, decorrente do modelo econômico centrado na pecuária, atividade que exige um contingente menor de trabalhadores. Nos primeiros anos da produção de maçãs, o trabalho nos pomares era realizado pelas famílias dos produtores e por um pequeno número de trabalhadores contratados. Com o progressivo aumento do número de pomares e da quantidade de maçãs produzida e com a implantação dos packing-houses na década de 1980, o município se aproximou de uma situação de pleno emprego (CORREIO VACARIENSE, 21/10/1988, p. 12). E, com o contínuo crescimento da produção e da produtividade dos pomares, passou a haver a necessidade de contratação de trabalhadores de outras cidades para a realização de atividades como a colheita das maçãs, gerando um mercado de trabalho sazonal no município, no qual há grande demanda por trabalhadores em determinados períodos e demissão em massa desses trabalhadores após o fim das respectivas atividades (CORREIO VACARIENSE, 08/05/1993, p. 5). A partir de meados da década de 
1990 e nos primeiros anos da década de 2000, esses trabalhadores sazonais passaram a vir de diversas cidades e regiões do Rio Grande do Sul (CORREIO VACARIENSE, 30/12/1995, s/p.; 13/01/1996, p. 3; 09/03/2002, p. 1) e, nos anos seguintes, também de outros estados do país, como Santa Catarina, Mato Grosso do Sul, Maranhão, entre outros.

Em relação ao perfil desses trabalhadores migrantes, eles são, na maioria, homens, com origens e histórias diversas. Dentre eles há pequenos agricultores assentados pela reforma agrária, acampados do MST, indígenas, agricultores familiares e assalariados que trabalham em diversas atividades no campo e nas cidades. "Muitos deles são trabalhadores jovens do campo, que saem de casa em busca de uma renda para ajudar a família" (CORREIO VACARIENSE, 13/01/1996, p. 3) e "uma parte das pessoas que vêm de fora são pequenos produtores que buscam uma alternativa de renda e sempre que termina uma safra já deixam praticamente acertado para retorno no ano seguinte" (CORREIO VACARIENSE, 30/12/1995, não paginado, grifos nossos).

Essa dinâmica migratória é resultado de fatores como a grande concentração de terras no país e, segundo Silva e Melo (2016), das desigualdades regionais, que fazem os trabalhadores migrarem em busca de mais oportunidades em outras regiões. Há diversos estudos que analisam esses movimentos migratórios, especialmente dos trabalhadores da agricultura familiar da região Nordeste do país para o trabalho assalariado nas colheitas da cana-de-açúcar e da laranja em estados como São Paulo. Segundo Menezes (2009), a migração em busca de trabalho é uma das estratégias de reprodução social do campesinato, na qual o trabalho realizado em regiões distantes busca garantir a sobrevivência da pequena propriedade e da família no local de origem.

Além dessa perspectiva de reprodução social, Pereira $(2015 ; 2019)$, ao analisar o trabalho migratório de piauienses para trabalhar na citricultura no estado de São Paulo, ressalta a capacidade de agência desses trabalhadores ao buscar melhores condições de vida e oportunidades de trabalho e que muitos deles consideram a migração como uma oportunidade de acesso ao mercado de trabalho formal e a uma série de direitos trabalhistas, como o seguro desemprego, menos acessíveis no local de origem, e que possibilitam sua manutenção econômica tanto durante a safra quanto na entressafra. Maciel (2012), por sua vez, aponta que essas migrações são consideradas pelos trabalhadores como uma oportunidade de "melhorar de vida", ou seja, de melhorar seu status social, o que ocorre por meio: 1) da possibilidade de aquisição de bens duráveis e não duráveis por meio do trabalho assalariado; 2) do acesso mais facilitado a direitos sociais, como saúde e educação; 3) da libertação dos esquemas de dominação em relação aos maridos, no caso das mulheres, e em relação aos pais, no caso dos homens jovens; 4) da possibilidade de circulação no espaço social e de criação de novas formas de vida.

$\mathrm{Na}$ produção de maçãs, as atividades que alimentam esse mercado sazonal são as relacionadas à produção agrícola, como o plantio, a adubação, a enxertia e a poda das macieiras, realizadas nos meses de inverno, o raleio, por volta do mês de dezembro e, especialmente, a colheita das maçãs entre os meses de janeiro e maio. Essas atividades são responsáveis pela contratação anual de um grande contingente de trabalhadores temporários, homens em sua maioria. A colheita é a atividade que exige o maior número de trabalhadores, e o número de contratações depende do tamanho da produção de cada ano, podendo variar entre 8 e 15 mil trabalhadores contratados anualmente no período entre janeiro e maio (Sindicalista do STR, entrevista, 26/02/2018).

São três as funções desenvolvidas nos pomares durante a colheita: colhedor, tratorista e monitor. O colhedor é aquele que coleta as maçãs da macieira, coloca-as dentro de uma sacola 
que ele carrega junto ao corpo até que ela esteja cheia e depois despeja seu conteúdo no bins ${ }^{7}$. O tratorista é o funcionário que anota o número de sacolas de maçãs colhidas que cada trabalhador deposita nos bins e depois os transporta do pomar até as centrais de classificação e embalagem. E o monitor ou capataz é o funcionário que supervisiona pelo menos cinco outros trabalhadores com o objetivo de garantir que as maçãs não sejam danificadas ao longo da colheita, uma vez que o valor delas é relativo à sua classificação pelo número de defeitos, de modo que quanto menor o número de defeitos de uma maçã, maior será seu valor de venda no mercado interno e externo. Por isso, o monitor verifica o modo como cada trabalhador colhe as maçãs e as deposita nos bins e como é feito seu transporte até o packing-house (RITZEL; PEDROSO, 2004).

Já as atividades de estocagem, classificação e embalagem funcionam ao longo do ano e são responsáveis pela geração de empregos permanentes, que, por sua vez, são ocupados majoritariamente por mulheres. De acordo com os relatos dos trabalhadores e trabalhadoras ao longo do trabalho de campo, o trabalho no packing-house das maiores empresas é dividido em dois turnos, um que começa de manhã e vai até o fim da tarde e outro que começa no fim da tarde e vai até a madrugada. Ainda de acordo com os relatos dos trabalhadores, as funções desempenhadas nas centrais de classificação e embalagem de maçãs são bem específicas, indicando ampla divisão e grande especialização do trabalho. As respostas para a pergunta "qual é o seu trabalho na empresa?" foram: "Eu conserto os bins quebrados", "Eu coloco as caixas de papelão com maçãs nos paletes" e "Eu coloco etiquetas nas caixas de maçã", por exemplo (Conversas informais com os trabalhadores, junho de 2018). Nos relatos dos trabalhadores também foi mencionada a questão da diferenciação dos trabalhadores nas empresas, com diferentes cores de uniforme para trabalhadores, supervisores e gerentes, o que demarca a hierarquia da empresa e uma distinção social que acaba estimulando a fragmentação de classe.

A intensa especialização do trabalho, com atividades repetitivas e que exigem trabalho semiqualificado, são características do padrão de produção fordista (ANTUNES, 2009) e foram mantidas no setor produtor de maçãs mesmo após a reestruturação produtiva, que estimulou o trabalho polivalente, multifuncional e qualificado em outros setores. Do mesmo modo, o trabalho com estoques de maçãs também foi mantido no setor, isso porque a produção de maçãs ocorre apenas nos primeiros meses do ano e toda essa produção precisa ser armazenada em enormes câmaras com temperatura e atmosfera controladas para ser vendida ao longo do restante do ano. Por outro lado, na linha das transformações decorrentes da reestruturação produtiva, houve a preocupação com o controle de qualidade ao longo do processo produtivo nas empresas, a terceirização de algumas etapas do processo produtivo, como a contratação de trabalhadores e as vendas das empresas, a predominância do trabalho flexível e a tentativa de reduções dos custos do trabalho, como será melhor visto nas seções seguintes.

A manutenção de algumas características do padrão de acumulação fordista simultaneamente à adoção de características do padrão de acumulação flexível está ligada à especificidade da produção agrícola. A produção agrícola tem uma dinâmica própria, de sazonalidade, associada e dependente da natureza, das estações do ano, diferentemente de indústrias como a automobilística, por exemplo, cuja disponibilidade de matérias-primas e cujas condições de produção não sofrem variações ao longo do ano. Assim, esses trabalhadores acabam desempenhando um trabalho altamente fragmentado e pouco qualificado, ao mesmo tempo em que a especificidade da produção agrícola favorece ainda mais a intensa flexibilização do trabalho.

\footnotetext{
${ }^{7}$ Bins são grandes caixas de madeira onde são depositadas as maçãs colhidas no pomar.
} 


\section{O SINDICATO DOS TRABALHADORES RURAIS DE VACARIA: REPRESENTAÇÃO E LUTA POR DIREITOS}

O Sindicato dos Trabalhadores Rurais de Vacaria, STR daqui por diante, foi a primeira forma de organização coletiva dos trabalhadores rurais no município de Vacaria e foi fundado, em abril de 1962, no distrito de Vila Ipê, uma das comunidades rurais do município. A criação do sindicato ocorreu por meio da mobilização de integrantes da Igreja Católica e de lideranças da comunidade, e sua principal base foram os produtores de base familiar, descendentes de imigrantes italianos, que trabalhavam para garantir a subsistência de suas famílias e tinham uma posição social subalterna em relação aos grandes fazendeiros, que dominavam a economia e a política local.

O reconhecimento estatal do sindicato por meio da investidura sindical ocorreu em 31 de novembro de 1965 (CORREIO VACARIENSE, 27/07/1990, s/p.). Apesar de os produtores de base familiar terem sido a principal base de trabalhadores na fundação e nas primeiras décadas de existência do STR, com o crescimento da fruticultura, especialmente da produção de maçãs, e da consolidação da cadeia produtiva da maçã, houve uma alteração nas bases do sindicato e os assalariados rurais passaram a ser a maior parcela dos associados e dos representados do sindicato. De modo geral, houve um crescimento significativo do número de associados do STR ao longo dos anos, que, de acordo com dados da revista comemorativa dos 50 anos do STR (STR VACARIA E MUITOS CAPÕES, 2015), na década de 1960, eram cerca de trezentos e, atualmente, de acordo com o sindicalista entrevistado (Sindicalista do STR, entrevista, 26/02/2018), são cerca de 7.700 associados, sendo cerca de 1.200 agricultores familiares e 6.500 assalariados rurais. E a representação do STR é realizada por uma diretoria composta por doze pessoas, sete homens e cinco mulheres, com origem nas diversas comunidades rurais do município, entre agricultores familiares, assalariados rurais e assentados da reforma agrária. Eles se dividem entre os cargos de diretores e seus suplentes, tesoureiro e conselheiros fiscais e seus suplentes (Sindicalista do STR, entrevista, 26/02/2018).

As ações do STR têm sido de grande importância para que os assalariados rurais conquistassem e mantivessem seus direitos e melhores condições de vida e trabalho. Isso foi possível pela articulação e luta dos sindicalistas e de sua atuação conjunta com outras entidades em prol de determinadas demandas. Estas, bandeiras de luta e repertórios de ação do sindicato, por sua vez, passaram por algumas transformações ao longo das décadas. A Constituição de 1988 e o crescimento do número de assalariados rurais no município, por exemplo, representaram um ponto de virada nas lutas sindicais dos trabalhadores rurais locais. Antes da promulgação da Carta Magna, as principais bandeiras de luta defendidas pelo STR foram a efetivação dos direitos trabalhistas, a regulamentação da seguridade social rural e sua equiparação à urbana, uma política agrícola mais favorável aos pequenos produtores e a realização da reforma agrária. Após a promulgação da Constituição, as bandeiras de luta do sindicato passaram a ser a implementação das leis estabelecidas pela Carta Magna, a padronização dos contratos de trabalho e melhores condições de vida e trabalho de forma mais ampla (CORREIO VACARIENSE, 03/04/2002, p. $5)$.

Por meio dessas bandeiras de luta, uma série de repertórios passou a ser adotada pelo STR, dentre os quais podem ser destacados o auxílio contínuo em questões de saúde, a luta pela construção das convenções coletivas de trabalho para os assalariados rurais, a luta pela formalização do trabalho e pelo cumprimento das convenções, a realização de greves para reivindicar o cumprimento de direitos, o trabalho de prestação de informações aos trabalhadores, o encaminhamento de denúncias de irregularidades ao Ministério Público do Trabalho e 
a participação em eventos nacionais dos assalariados rurais, como a Primeira Marcha dos Assalariados Rurais, realizada em Brasília-DF em 2012.

A atuação do STR em relação às questões de saúde e previdência permeou toda sua história. Há décadas e até hoje o sindicato oferece atendimento para encaminhar aposentadorias e auxílios sociais, serviços médicos, odontológicos e outros auxílios para questões de saúde dos trabalhadores e de suas famílias. Atualmente, o STR conta com dois médicos e dois dentistas que atendem no próprio sindicato todos os dias. O STR também firmou convênios que favorecem seus associados com alguns laboratórios para a realização de exames e com a prefeitura e as farmácias para aquisição de medicamentos a preços mais acessíveis. Além disso, o sindicato também conta com a atuação periódica de profissionais de medicina alternativa e de quiropraxia.

Ao longo do trabalho de campo, em todos os dias em que estivemos no STR havia vários associados esperando por consultas com os médicos e dentistas do sindicato. Além dessa atuação de forma contínua, há cinco anos o STR e a Secretaria de Saúde do município realizam o "Plano Safra", que oferece assistência médica e odontológica para os assalariados rurais temporários que trabalham na colheita da maçã. O programa funciona nos meses de janeiro, fevereiro e março. Nesse período, o sindicato abre à noite, uma vez por semana, a fim de que os assalariados, que trabalham durante todo o dia, possam ser atendidos pelo dentista do sindicato e pelo médico da Secretaria da Saúde do município. De acordo com o relato do sindicalista entrevistado, cerca de seiscentos assalariados temporários são atendidos anualmente pelo Plano Safra. A prestação de serviços de saúde pelo sindicato e sua ampla utilização pelos trabalhadores rurais locais podem ser entendidas, para além de assistencialismo, como uma forma de o sindicato suprir uma lacuna, de atender uma série de demandas com as quais o Estado não consegue arcar e que os trabalhadores não têm condições de atender na rede particular de saúde.

Outra atividade de grande importância realizada pelo STR é a negociação anual das convenções coletivas de trabalho $(\mathrm{CCT})^{8}$. A primeira CCT dos trabalhadores rurais de Vacaria foi realizada em 1994, entre o Sindicato dos Trabalhadores Rurais de Vacaria e o Sindicato Rural de Vacaria, e sua realização foi resultado de anos de insistência do STR e de negociação com o sindicato patronal. A realização das CCT foi uma importante conquista para os assalariados rurais locais, uma vez que estabeleceu para eles um salário-base, o mínimo a ser pago aos trabalhadores, e padronizou garantias e condições de trabalho. Anteriormente, os contratos e salários eram individualizados e dependiam do poder de barganha de cada trabalhador. Essa primeira CCT teve vigência de um ano, com validade de 1.\%/05/1994 a 30/04/1995, e continha trinta e cinco cláusulas. Ao longo dos anos de negociação, os termos das convenções foram aumentados, sendo especificados, alterados e/ou substituídos, mas a maior parte dos conteúdos se manteve, apesar de sua redistribuição entre as cláusulas.

A negociação das convenções coletivas é um exercício de barganha, no qual os representantes das classes fazem uso de seus capitais para melhorar ou manter suas posições sociais em detrimento da classe oposta. Essa prática faz parte do jogo que se desenvolve no

\footnotetext{
8 São os acordos gerados pelas negociações realizadas entre os sindicatos de empregados e de empregadores de determinada categoria profissional. Por meio dessas negociações é firmado um contrato cujas cláusulas são aplicáveis a toda uma categoria de trabalhadores, em certa área de abrangência territorial, por um período de tempo determinado, como um ano, no caso dos trabalhadores rurais de Vacaria. Essas cláusulas estabelecem regras sobre as condições de trabalho, o nível salarial, as obrigações e direitos de empregados e empregadores, entre outros assuntos, indo além do que já é previsto pela legislação trabalhista. Toda convenção coletiva de trabalho deve ser protocolada e homologada pelo Ministério do Trabalho para ser legalizada e seu descumprimento gera penalizações legais. Com a aprovação da Reforma Trabalhista de 2017, as cláusulas convencionadas passaram a ter prevalência sobre a legislação.
} 
campo político, no qual as posições são estruturais e devem ser defendidas, tanto em busca de posições melhores quanto para fins de manutenção dos representados (BOURDIEU, 1989). Assim, os conteúdos firmados nas convenções coletivas refletem as demandas sociais em disputa e a força política dos representantes dos trabalhadores e da classe patronal. Embora a classe patronal seja detentora de mais capitais e tenha maior facilidade de impor suas demandas, o STR de Vacaria também tem alcançado vitórias para os assalariados rurais.

Por meio da análise dos conteúdos das cláusulas das convenções realizadas entre 1994 e 2017 foi possível enquadrar as questões em disputa entre os trabalhadores e os empregadores e seus respectivos sindicatos em quatro grandes conjuntos: 1) a remuneração; 2) as condições de trabalho; 3 ) as questões legais e 4) as divergências. O primeiro grupo temático de questões se refere à remuneração, abrangendo questões como os salários, as horas-extra, os adicionais ao salário, como o adicional noturno, e outros auxílios, de ordem financeira. $\mathrm{O}$ salário é um dos pontos mais importantes e que ocupa a maior parte do tempo de negociação das convenções coletivas. O segundo conjunto de questões abrangidas pelas convenções coletivas de trabalho dos trabalhadores rurais de Vacaria se refere às condições de trabalho oferecidas aos trabalhadores locais, passando por questões como a garantia de trabalho formal, a flexibilidade dos contratos, as condições de alojamento, alimentação e transporte oferecidas aos trabalhadores, a questão da insalubridade e o fornecimento de instrumentos de trabalho e de equipamentos de proteção individual (EPIs), por exemplo. Já o terceiro grupo de questões abrangidas pelas convenções coletivas se refere a questões legais, estabelecidas pela legislação trabalhista brasileira e reforçadas ao longo das convenções coletivas. Dentre elas se destacam aquelas relativas à vigência e à abrangência das $\mathrm{CCT}$, a presença do STR nas rescisões de contrato e o pagamento do imposto sindical (contribuições sindicais). E o quarto grupo temático de questões se refere às divergências entre empregadores e trabalhadores e seus respectivos sindicatos e as formas de solucioná-las. Nesses termos, nas cláusulas das convenções analisadas sobressaem questões como a forma de resolução das divergências na aplicação da convenção, as ações trabalhistas, a "comissão de conciliação prévia", a atuação do STR nos locais de trabalho e as sanções aos empregadores no caso do descumprimento do que a convenção estabelece.

Ao longo dos anos de negociações, as principais conquistas para os trabalhadores em termos de remuneração foram o estabelecimento de um salário-base, a regulamentação do valor da hora-extra de trabalho e da hora de trabalho noturna, a redução dos descontos de alimentação, transporte e moradia e a garantia da remuneração dos dias de chuva em que o trabalhador fica à disposição do empregador, mas não pode realizar sua função contratual e, especialmente, os ganhos reais de salário da categoria, conforme pode ser verificado na Tabela 1.

Os dados da Tabela 1 demonstram que o salário nominal da categoria sempre foi um pouco maior que o salário mínimo nacional, tornando o trabalho no município mais atrativo para os trabalhadores. Nesse sentido, o sindicalista do STR (entrevista, 26/02/2018) também lembrou que, no geral, como o STR de Vacaria tem conseguido ganhos de salário mais elevados que os sindicatos de outros municípios produtores de maçãs, os trabalhadores que vêm de longe preferem trabalhar em Vacaria porque salários maiores significam um ganho maior, uma maior compensação pelo afastamento da família e proporcionam mais condições de ajudar a unidade familiar no caso dos pequenos produtores, que se assalariam temporariamente.

\footnotetext{
9 Comissões de conciliação prévia foram uma ferramenta de conciliação de divergências na relação capital-trabalho estabelecida pela Lei . $^{\circ}$ 9.958/2000. Ela previa a formação de comissões com integrantes dos sindicatos de trabalhadores e patronal nas quais deveriam ser discutidas as divergências trabalhistas na presença do trabalhador e do empregador em questão, buscando estabelecer um acordo e evitando a geração de um processo na Justiça do Trabalho. Em Vacaria, essas comissões existiram de 2000 a 2008. A extinção delas foi decorrente de um processo de inconstitucionalidade da lei que as determina (BARROS, 2011).
} 
Em relação à inflação e em termos de salário real, os reajustes oscilaram muito ao longo dos anos, apresentando ganhos e perdas aos trabalhadores. Em alguns anos, como de 1995 a 1997, de 2003 a 2006, em 2009, de 2011 a 2014 e em 2016 e 2017, o reajuste do saláriobase ficou acima da inflação, sendo praticamente o dobro do índice de inflação em quase todos os anos, garantindo ganhos reais de salário aos trabalhadores locais. Já nos anos de 2001, 2002, 2007, 2008, 2010 e 2015, o reajuste salarial dos trabalhadores rurais de Vacaria foi equivalente à inflação do mesmo ano, ou seja, eles não tiveram ganhos reais.

Além do pagamento do salário-base estabelecido pelas convenções coletivas, as empresas também realizam pagamentos por produtividade, vinculados ao número de sacolas de maçãs colhidas por dia. Esses pagamentos, porém, são negociados de forma individual entre cada empresa e seus funcionários, não havendo qualquer controle por parte do sindicato ou do Estado, de acordo com o que foi observado ao longo do trabalho de campo. Para Alves (2006), que analisou o pagamento por produção na colheita da cana-de-açúcar em São Paulo, essa prática é danosa aos trabalhadores, uma vez que ela transfere a eles a responsabilidade pelo ritmo de trabalho e vincula os lucros da empresa a esse ritmo. Com isso, práticas como a demissão dos trabalhadores menos produtivos e o estímulo à competição entre os demais garantem uma maior taxa de lucro às empresas, ao custo de esforços extenuantes dos trabalhadores, que sacrificam sua saúde em busca de maior remuneração. Como essa forma de pagamento também ocorre nos pomares de maçãs, possivelmente promovem situações semelhantes.

\section{TABELA 1 - SALÁRIO MÍNIMO NACIONAL, INFLAÇÃO E SALÁRIO-BASE DOS TRABALHADORES RURAIS DE VACARIA (1994-2017)}

\begin{tabular}{|c|c|c|c|c|c|}
\hline \multirow[t]{2}{*}{ Ano } & \multicolumn{2}{|c|}{ Salário mínimo nacional } & \multirow{2}{*}{$\frac{\text { Inflação }}{\text { INPC }}$} & \multicolumn{2}{|c|}{ Salário da categoria } \\
\hline & Salário & Var. $\%$ & & Salário base & Var. $\%$ \\
\hline 1994 & $\mathrm{R} \$ 64,79$ & - & 929,32 & $\mathrm{R} \$ 81,00$ & - \\
\hline 1995 & $\mathrm{R} \$ 100,00$ & $54,34 \%$ & 21,98 & $\mathrm{R} \$ 120,00$ & $48,15 \%$ \\
\hline 1996 & $\mathrm{R} \$ 112,00$ & $12,00 \%$ & 9,12 & $\mathrm{R} \$ 149,60$ & $23,67 \%$ \\
\hline 1997 & $\mathrm{R} \$ 120,00$ & $7,14 \%$ & 4,34 & $\mathrm{R} \$ 165,00$ & $10,29 \%$ \\
\hline 1998 & $\mathrm{R} \$ 130,00$ & $8,33 \%$ & 2,49 & $\mathrm{R} \$ 175,00$ & $6,06 \%$ \\
\hline 1999 & $\mathrm{R} \$ 136,00$ & $4,62 \%$ & 8,43 & $\mathrm{R} \$ 187,00$ & $6,86 \%$ \\
\hline 2000 & $\mathrm{R} \$ 151,00$ & $11,03 \%$ & 5,27 & $\mathrm{R} \$ 204,60$ & $9,41 \%$ \\
\hline 2001 & $\mathrm{R} \$ 180,00$ & $19,21 \%$ & 9,44 & $\mathrm{R} \$ 226,60$ & $10,75 \%$ \\
\hline 2002 & $\mathrm{R} \$ 200,00$ & $11,11 \%$ & 14,74 & $\mathrm{R} \$ 261,80$ & $15,53 \%$ \\
\hline 2003 & $\mathrm{R} \$ 240,00$ & $20,00 \%$ & 10,38 & $\mathrm{R} \$ 316,80$ & $21,01 \%$ \\
\hline 2004 & $\mathrm{R} \$ 260,00$ & $8,33 \%$ & 6,13 & $\mathrm{R} \$ 345,40$ & $9,03 \%$ \\
\hline 2005 & $\mathrm{R} \$ 300,00$ & $15,38 \%$ & 5,05 & $\mathrm{R} \$ 380,00$ & $10,02 \%$ \\
\hline 2006 & $\mathrm{R} \$ 350,00$ & $16,67 \%$ & 2,81 & $\mathrm{R} \$ 412,00$ & $8,42 \%$ \\
\hline 2007 & $\mathrm{R} \$ 380,00$ & $8,57 \%$ & 5,16 & $\mathrm{R} \$ 437,80$ & $6,26 \%$ \\
\hline 2008 & $\mathrm{R} \$ 415,00$ & $9,21 \%$ & 6,48 & $\mathrm{R} \$ 485,00$ & $10,78 \%$ \\
\hline 2009 & $\mathrm{R} \$ 465,00$ & $12,05 \%$ & 4,11 & $\mathrm{R} \$ 520,00$ & $7,22 \%$ \\
\hline 2010 & $\mathrm{R} \$ 510,00$ & $9,68 \%$ & 6,47 & $\mathrm{R} \$ 556,60$ & $7,04 \%$ \\
\hline 2011 & $\mathrm{R} \$ 545,00$ & 6,86 & 6,08 & $\mathrm{R} \$ 618,20$ & $11,07 \%$ \\
\hline
\end{tabular}




\begin{tabular}{cccccc}
\hline Ano & \multicolumn{2}{c}{ Salário mínimo nacional } & \multicolumn{2}{c}{ Inflação } & \multicolumn{2}{c}{ Salário da categoria } \\
\hline & Salário & Var. $\%$ & INPC & Salário base & Var. \% \\
\hline 2012 & $\mathrm{R} \$ 622,00$ & $14,13 \%$ & 6,20 & $\mathrm{R} \$ 710,60$ & $14,95 \%$ \\
\hline 2013 & $\mathrm{R} \$ 678,00$ & $9,00 \%$ & 5,56 & $\mathrm{R} \$ 789,00$ & $11,03 \%$ \\
\hline 2014 & $\mathrm{R} \$ 724,00$ & $6,78 \%$ & 6,23 & $\mathrm{R} \$ 883,00$ & $11,91 \%$ \\
\hline 2015 & $\mathrm{R} \$ 788,00$ & $8,84 \%$ & 11,28 & $\mathrm{R} \$ 1.012,00$ & $14,61 \%$ \\
\hline 2016 & $\mathrm{R} \$ 880,00$ & $11,68 \%$ & 6,58 & $\mathrm{R} \$ 1.113,20$ & $10,00 \%$ \\
\hline 2017 & $\mathrm{R} \$ 937,00$ & $6,48 \%$ & 2,07 & $\mathrm{R} \$ 1.185,80$ & $6,52 \%$ \\
\hline
\end{tabular}

Fonte: Elaborado pelos autores com base em dados do Dieese, Ipea e STR.

* No mês de maio de cada ano.

Em relação às condições de trabalho, as principais conquistas do STR e dos trabalhadores foram a ampliação da formalização do trabalho por meio da instituição da obrigatoriedade da assinatura da carteira de trabalho e previdência social (CTPS) de todos os trabalhadores já na convenção coletiva de 1994 e do cumprimento da obrigatoriedade do fornecimento de EPIs, também desde 1994. Por outro lado, nesses termos, também houve significativas vitórias da classe patronal, como a regulamentação de formas de contratação altamente flexíveis, a saber: 1) os contratos que possibilitam a alteração de atividades, de turnos e de horários na convenção coletiva de 1994; 2) o estabelecimento, na convenção coletiva de 1999, da possibilidade de contratos que podem ser interrompidos por períodos de vinte a trinta dias, vigentes para o período entre o fim da colheita de uma variedade de maçã e o início de outra, quando o empregador fica desobrigado a pagar o salário do trabalhador; 3) a jornada $12 \times 36$, aquela na qual os trabalhadores têm doze horas de trabalho consecutivo seguidas de um descanso de trinta e seis horas, também instituída na convenção coletiva de 1999 e 4) os contratos por tempo parcial - o "contrato de safra e determinado" - justificados pela sazonalidade das atividades desenvolvidas, incluídos na convenção coletiva de 2006. A incorporação desses modelos de flexibilização dos contratos e do trabalho pode ser explicada pelas tendências impostas pela reestruturação produtiva que passou a afetar o setor a partir da década de 1990 e do poder de mobilização de capitais e de barganha do sindicato patronal para implementar esses modelos.

Em relação ao terceiro e quarto grupos de questões presentes nas convenções coletivas, as questões legais, que foram afetadas pela Reforma Trabalhista de 2017, serão discutidas posteriormente. Já as cláusulas referentes às possíveis divergências entre o sindicato de trabalhadores e patronal e seus respectivos representados sobre questões não abrangidas ou esclarecidas pelas convenções não sofreram alterações ao longo do tempo, exceto pela extinção das comissões de conciliação prévia. Esse conjunto de cláusulas propõe formas de controle da atuação de ambos os sindicatos, especialmente do STR, e estabelece a importância das divergências serem negociadas, da busca pela conciliação e não do enfrentamento e de soluções "através da via amigável" entre os diretores de ambos os sindicatos (CCT, 1994, cláusula 34. ․, p. 7).

Apesar da resistência patronal, a partir do momento em que as convenções coletivas negociadas foram legitimadas pelo Ministério do Trabalho e entraram em vigência, o STR passou a divulgar os direitos dos trabalhadores rurais e a sanar suas dúvidas, bem como a exigir o cumprimento das convenções coletivas por todos os empregadores rurais. De acordo com o relato de um sindicalista entrevistado (Sindicalista do STR, entrevista, 26/02/2018), no caso de os trabalhadores procurarem o sindicato por irregularidades trabalhistas e pelo não cumprimento do estabelecido pela convenção coletiva, o sindicato entrava em contato com o empregador ou 
empresa, procurava resolver a situação e, diante de um impasse, advertia sobre a possibilidade de o empregador "ir para a justiça do trabalho" pelo não cumprimento da CLT ou da convenção coletiva firmada com o sindicato patronal. De forma geral, esse modo de atuação do sindicato alcançou bons resultados ao longo do tempo, o que pode ser explicado pelo capital político acumulado por essa instituição e por seus dirigentes ao longo de sua história, o que, por um lado, consolidou o processo de representação classista e, por outro, favoreceu a luta por direitos. Um desses resultados foi a ampliação da formalização do trabalho rural, alcançada e mantida no município há vários anos, fato mencionado por vários sindicalistas do STR ao longo do trabalho de campo e confirmado pelo dirigente do sindicato patronal (entrevista, 25/06/2018).

Por outro lado, também houve situações de impasse, para as quais a resposta do sindicato e dos trabalhadores foram as greves. De acordo com informações do sindicalista entrevistado (entrevista, 26/02/2018), o sindicato participou da organização de três greves de assalariados rurais em empresas produtoras de maçã. A primeira delas foi na empresa G., em 2010. A segunda foi na empresa L., em 2014, por falta de pagamento e pelo não cumprimento da convenção coletiva. A terceira foi feita na empresa I., em 2016, por falta de pagamento e durou quinze dias, até que a empresa pagou todas as dívidas com os trabalhadores. Segundo o relato do sindicalista entrevistado, nas três greves os trabalhadores contataram o STR, foi criada uma comissão de negociação com representantes dos trabalhadores, do sindicato e das empresas, e a decisão pela greve foi tomada em assembleia devido à falta de avanço nas negociações. Ao longo das greves, os trabalhadores e sindicalistas passaram os dias nas empresas e nos três casos os trabalhadores foram bem-sucedidos e acabaram recebendo o que as empresas não haviam pagado. Por fim, houve também casos de irregularidades constatadas pelo sindicato e que foram denunciadas ao Ministério Público do Trabalho, cuja atuação também foi fundamental para a garantia dos direitos dos trabalhadores rurais de Vacaria.

\section{IRREGULARIDADES TRABALHISTAS E ATUAÇÃO DAS INSTITUIÇÕES DO ESTADO}

O Ministério Público do Trabalho ${ }^{10}$ é uma instituição cuja atuação é de grande importância para a proteção dos trabalhadores. No caso de Vacaria, essa atuação, em conjunto com outras instituições, significou avanços nas condições de trabalho dos assalariados rurais, especialmente dos temporários. Como vimos anteriormente, nos anos finais da década de 1990 e no início dos anos 2000, houve um crescimento expressivo no número de trabalhadores empregados na cadeia produtiva da maçã e de contratações de trabalhadores de regiões cada vez mais distantes. Com isso, essas empresas passaram a oferecer alojamento e alimentação para esses trabalhadores.

Contudo, algumas dessas empresas passaram a improvisar alojamentos inadequados e a oferecer uma alimentação extremamente precária, além de cometerem outras irregularidades. Por meio das denúncias de alguns trabalhadores ao STR e às mídias locais, essas irregularidades passaram a ser amplamente divulgadas pela mídia local e estadual. Entre os principais problemas denunciados estavam condições de trabalho análogas à escravidão (chamado na imprensa de "trabalho escravo"), trabalho infantil, alojamentos sem estruturas adequadas e higiene, falta de refeitórios e alimentação inadequada, falta de transporte às cidades de origem após a rescisão dos contratos, falta de água potável, falta de equipamentos de proteção e intoxicação por

\footnotetext{
${ }^{10}$ Um dos ramos do Ministério Público da União, trata-se de uma instituição de Estado independente dos três poderes cujo objetivo é fiscalizar as relações trabalhistas e garantir o cumprimento da legislação trabalhista, coibindo abusos e mediando a relação entre trabalhadores e empregadores para garantir o interesse público.
} 
produtos químicos (TREZZI, 2002, p. 6; DUARTE, 2002, p. 6; SINDICALISTA DO STR, entrevista, 26/02/2018). As reportagens publicadas traziam alguns relatos dos trabalhadores, como o transcrito a seguir, do safrista Jean da Silva, de trinta três anos, que trabalhou por três anos na safra da maçã em uma empresa de Vacaria.

\footnotetext{
"Eu sou um ser humano e preciso ter o mínimo de respeito comigo, para as macieiras não volto nunca mais". [...] "Não é trabalho escravo porque temos liberdade para sair, mas eles não respeitam a condição de ser humano". Ele conta que havia menores contratados, a água era servida em galões de produtos químicos lavados e não havia refeitório. "Muitas vezes a comida que a gente levava de casa azedava, porque não tinha geladeira, daí ficava o dia todo sem comer nada". Silva relata ainda que era orientado a se esconder entre os pomares quando houvesse autuação da fiscalização. "Eles mandavam a gente levar carteira de trabalho, mas era só para dizer que estavam encaminhando a contratação se tivesse batida", conta, afirmando ter se escondido umas duas ou três vezes (DUARTE, 2002, p. 6, grifos nossos).
}

Por meio de ampla divulgação dessas irregularidades e das denúncias encaminhadas por intermédio do STR de Vacaria, foi organizada a ação conjunta do Ministério Público, do Ministério Público do Trabalho e da Polícia Federal nos pomares de Vacaria, com uma série de buscas e fiscalizações. No final de 2001, por exemplo, foi criada uma força-tarefa, formada por promotores estaduais e federais, membros da Polícia Federal e promotores do trabalho, que coletaram dezenas de depoimentos em seis meses de investigação, indicando "condições sub-humanas de trabalho para parte dos 14 mil safristas" (TREZZI, 2002, p. 6). Essas investigações foram seguidas de uma série de fiscalizações nas empresas e pomares, de autuações das empresas envolvidas e de audiências judiciais que estabeleceram o pagamento de multas e da assinatura de termos de ajuste de conduta por parte das empresas que apresentavam irregularidades trabalhistas.

Devido à gravidade das denúncias realizadas, muitas empresas foram autuadas e houve o cancelamento de contratos firmados de venda de maçãs por parte dos compradores, como forma de protesto em relação às irregularidades cometidas. Nesse contexto, também foi realizada uma grande audiência pública em Vacaria no dia dez de maio de 2002, promovida pela Comissão de Cidadania e Direitos Humanos da Assembleia Legislativa do Rio Grande do Sul. A audiência teve como objetivo discutir as denúncias e o trabalho nos pomares e mobilizou grande parte das instituições e da comunidade local. O prefeito de Vacaria, Ângelo Pegoraro (PP), disse na audiência: "Acredito que tais manchetes [sobre trabalho escravo] foram longe demais, trazendo grandes prejuízos para o município. Prova está, que contratos firmados agora estão sendo cancelados". Na ocasião, o deputado estadual Francisco Appio (PP) também criticou a "denúncia que veio manchar o nome de Vacaria, nacional e internacionalmente" (CORREIO VACARIENSE, 15/05/2002, p. 4). Ao longo da audiência, além dos políticos locais, os representantes das empresas e da classe patronal também alegaram que não havia provas concretas da existência de condições análogas à de trabalho escravo e minimizaram a situação, alegando que as denúncias sobre as más condições de trabalho eram infundadas e desproporcionais à realidade.

Contrariamente, a procuradora do Ministério Público do Trabalho, Eliane Lucina, disse: "Verificamos, sim, condições muito ruins e ficamos bastante preocupados, são degradantes" e que "Laudos comprovaram que [a água oferecida aos safristas pelas empresas] não é potável, temos relatos de safristas que precisaram ser internados depois de beber a água”. E, ao falar das cooperativas que contratam trabalhadores em suas cidades de origem, a procuradora disse que "não é possível que todos os dias sejam encontradas pessoas retornando a pé para suas cidades 
por falta de transporte" (DUARTE, 2002, p. 6). Em relação às cooperativas que intermediavam a contratação dos trabalhadores, os "gatos", o que ocorria era que as empresas traziam os trabalhadores de suas cidades de origem no interior do Rio Grande do Sul para Vacaria, mas não os levavam de volta ao fim do contrato e não ofereciam qualquer tipo de auxílio. Diante dessa situação, os trabalhadores procuravam o STR, que, de acordo com o relato de um sindicalista entrevistado, acabou abrindo uma rubrica em seu orçamento para ajudar os assalariados rurais na aquisição de passagens rodoviárias para suas cidades de origem.

Por meio dessa audiência pública, o Ministério Público expediu uma série de recomendações às empresas produtoras de maçãs, orientando os procedimentos que os empregadores deveriam tomar para a contratação de trabalhadores para a safra da maçã. Feito isso, membros da Procuradoria Regional do Trabalho da 4. ${ }^{\text {a }}$ Região desenvolveram uma forçatarefa para fiscalizar o cumprimento, por parte das empresas, das medidas estabelecidas pelo Ministério Público (CORREIO VACARIENSE, 13/02/2004, p. 13). Esse conjunto de ações trouxe resultados positivos para os trabalhadores. O procurador do trabalho Philippe Gomes Jardim, disse, considerando as fiscalizações realizadas, que

Constatamos, de uma forma geral, que os grandes empregadores da região têm atendido, de uma certa forma, as recomendações do MP. Infelizmente, o que também constatamos é que nas pequenas e médias propriedades ainda há um conjunto de irregularidades que exigem uma atuação mais forte tanto do Ministério do Trabalho quanto do Ministério Público do Trabalho (CORREIO VACARIENSE, 13/02/2004, p. 13, grifos nossos).

O rápido cumprimento das recomendações do Ministério Público pelas grandes empresas pode ser explicado pelo receio do cancelamento dos contratos de exportação de maçãs. Segundo Silva e Melo (2016), no caso das denúncias sobre o trabalho degradante nos canaviais paulistas, as tentativas de adequação em relação às condições de trabalho e de camuflagem das reais condições de trabalho negociadas entre as empresas e o Estado tiveram como objetivo principal garantir a continuidade das exportações. Isso ocorre porque mercados consumidores como dos países europeus são exigentes em termos de questões como sustentabilidade social e ambiental dos produtos por eles adquiridos. É o que Dupas (2005, p. 188) chama de "consumidor politizado" dentro da lógica do capitalismo global, ou seja, o consumidor que utiliza seu poder de deixar de comprar, optando por produtos alternativos, a fim de penalizar determinado produto ou produtor em decorrência de danos cometidos por este ao meio ambiente, aos trabalhadores ou a países pobres, por exemplo.

Desse modo, irregularidades trabalhistas e ambientais no processo de produção são um entrave às exportações, o que levou as empresas exportadoras de maçã de Vacaria a se adequar para garantir a continuidade de sua estratégia de exportação e de preferência de vendas no mercado externo. Já em relação aos pequenos e médios produtores, a maior dificuldade para a realização das adequações estipuladas pode ser explicada pela necessidade de redução dos custos de produção e pela opção de fazê-lo em termos de custos do trabalho. Essa escolha foi realizada em um cenário de reestruturação produtiva e, possivelmente, teve como objetivo tentar manter a competitividade das empresas menores diante de um mercado dominado por grandes empresas exportadoras, altamente capitalizadas e mais competitivas. Por outro lado, apesar da demora de resposta das empresas menores, de forma geral, as adequações das empresas produtoras de maçãs de Vacaria ocorreram rapidamente. Em 2003, por exemplo, de acordo com Cláudio Menezes, fiscal do Ministério do Trabalho entrevistado para uma reportagem ao jornal Correio Vacariense (15/03/2003, s/p.), 
Nas fiscalizações que foram realizadas, realmente se encontravam alojamentos de plástico, péssimas condições de habitabilidade, sem água potável e locais para as pessoas tomarem banho. Tudo isso se encontrava em precárias condições. Hoje, você vai às empresas e encontra locais bem instalados de alvenaria, bom espaço para as pessoas tomarem banho, fazerem a sua higiene e lavarem a roupa, e isso já tem surtido um efeito positivo (CORREIO VACARIENSE, 15/03/2003, s/p.).

Essa tendência de implementação de melhores condições de trabalho tem se consolidado ao longo do tempo, em grande parte pela fiscalização contínua do STR e de órgãos como o Ministério Público e o Ministério Público do Trabalho. Segundo os relatos dos sindicalistas do STR, atualmente as condições de trabalho e alojamento oferecidas para os trabalhadores que colhem maçãs são mais adequadas e dignas, da mesma forma que a alimentação oferecida aos trabalhadores é determinada por nutricionistas e ocorre em refeitórios limpos e organizados. Ainda de acordo com esses relatos, diferentemente dos problemas encontrados na década de 1990 e no começo dos anos 2000, como a expressiva informalidade e condições de trabalho precárias, nos últimos anos os problemas trabalhistas mais frequentes, de forma geral, se referem a questões como irregularidades no pagamento de horas-extra e nos depósitos no fundo de garantia (FGTS) (Conversas informais com lideranças sindicais, fev. e jun. de 2018; set. de 2019).

\section{NOVO PADRÃO DE REGULAÇÃO SOCIAL DO TRABALHO NO PÓS- REFORMA TRABALHISTA?}

A dinâmica institucional apresentada nas seções anteriores sofreu alterações após a aprovação da Reforma Trabalhista de 2017, que vem gerando reflexos tanto nas convenções coletivas de trabalho de 2018 e 2019 quanto no funcionamento e na atuação de instituições como os sindicatos locais e a Justiça do Trabalho. As duas principais leis da Reforma são a n. ${ }^{\circ} 13.467 / 2017$, que alterou 201 pontos da CLT, e a n. ${ }^{\circ} 13.429 / 2017$, que permitiu a terceirização do trabalho para todos os tipos de atividade.

Segundo Krein (2018), dentre as principais mudanças propostas pela Reforma Trabalhista estão: 1) as alterações nas formas de contratação, como a ampliação do contrato a tempo parcial, a introdução do contrato intermitente, a extensão da contratação temporária e a possibilidade de contratação continuada de trabalhadores autônomos; 2) a flexibilização da jornada de trabalho, por meio da ampliação de mecanismos como o banco de horas e da jornada $12 \times 36$, e a redução dos custos do tempo que o trabalhador fica à disposição do empregador, mas não está efetivamente trabalhando, como pelo fim do cômputo das horas in itinere na jornada paga; 3) a remuneração variável por meio do estímulo aos programas de participação nos lucros e resultados, pela possibilidade de pagamento do trabalhador com bens, bônus e serviços e pelo pagamento por desempenho individual ou por produtividade; 4) mudanças que afetam o sindicalismo, como a prevalência do negociado sobre o legislado, a extinção do imposto sindical, a possibilidade de negociação individual dos contratos de trabalho, a realização das rescisões de contrato sem a presença do sindicato e a eliminação da ultratividade; 5) alterações que fragilizam a Justiça do Trabalho, como os limites à formulação de jurisprudências pelo Tribunal Superior do Trabalho e que criam obstáculos ao seu acesso para os trabalhadores, como o pagamento pelos custos das perícias aos proponentes das ações e o pagamento dos honorários do advogado da parte vencedora pela parte vencida na ação, e a fragilização da fiscalização.

Essa reforma é de cunho neoliberal, e alguns autores, como Krein (2018), usam o termo contrarreforma para defini-la, justamente pelos retrocessos em termos da regulação social e dos direitos dos trabalhadores decorrentes da nova legislação. De acordo com Valadares 
et al. (2017), a Reforma Trabalhista trouxe consequências diretas para os trabalhadores rurais, como o aumento da precarização do trabalho, e consequências indiretas, como a ampliação da exploração do trabalho informal como reflexo da flexibilização no trabalho formal, uma vez que este último serve de parâmetro para o primeiro, e a redução da renda da agricultura familiar no caso dos pequenos produtores que se assalariam temporariamente para complementar a renda familiar.

Para os autores, os principais pontos da Reforma Trabalhista que afetam os trabalhadores rurais são a terceirização, as mudanças na jornada de trabalho e as novas formas de contratação. A possibilidade de terceirização de todas as atividades da empresa é uma forma de flexibilização do limite à exploração do trabalho, uma vez que os trabalhadores terceirizados têm, em geral, piores condições de trabalho que os contratados diretamente. Além disso, a terceirização permite a intermediação da contratação por empreiteiros e cooperativas de trabalho (os “gatos"), contribuindo para o crescimento da desregulamentação e da informalidade.

Já a mudança na regulação da jornada de trabalho se refere ao fato de que o tempo de deslocamento ao local de trabalho e de retorno à residência pelo trabalhador deixou de ser contabilizado na jornada de trabalho, logo, o empregador é desobrigado do pagamento do deslocamento, que é repassado ao trabalhador, significando uma redução direta da remuneração, especialmente para os assalariados rurais que trabalham em propriedades muito afastadas. E, por fim, a reforma amplia as formas de contração, permitindo a criação de vínculos mais precários e que podem substituir o trabalho permanente, que vinha garantindo melhores salários e maior segurança para os trabalhadores rurais.

Em Vacaria, em termos das instituições que representam os trabalhadores rurais do município, houve duas dinâmicas distintas em relação à Reforma Trabalhista. Por um lado, ela legalizou práticas como a flexibilização dos contratos e jornadas, que já eram convencionados pelos sindicatos e válidos para os assalariados rurais locais. Por outro lado, nas convenções coletivas de 2018 e 2019, os sindicatos de trabalhadores e patronal convencionaram cláusulas que mantiveram práticas sociais eliminadas pela reforma, como as contribuições sindicais e a obrigatoriedade da participação do STR nas rescisões de contrato. Essas possibilidades já foram apontadas por autores como Krein (2018), segundo o qual a reforma foi uma regulamentação de práticas que já ocorriam no mercado de trabalho brasileiro, bem como uma maneira de permitir novas possibilidades de apropriação do trabalho pelos empregadores. Mas, por outro lado, apesar do que a nova legislação estabelece, a realidade é dialética, e os agentes sociais tendem a buscar novas estratégias e formas de ação e organização diante das mudanças propostas pela reforma. Uma das questões que tornou isso possível foi a continuidade do poder de normatização das relações de trabalho pelas convenções coletivas, que podem validar ou não o conteúdo da reforma parcialmente ou em sua totalidade.

Em relação às alterações na legislação trabalhista, como mencionado anteriormente, há anos as convenções coletivas de trabalho dos trabalhadores rurais de Vacaria continham cláusulas que flexibilizavam os contratos e a jornada de trabalho. Exemplos disso são as que permitiam os contratos de safra e determinados e sua interrupção sem remuneração por até 20/30 dias, as alterações de atividades, de turnos e de horários conforme as necessidades da empresa e a jornada $12 \times 36$. E em termos de remuneração, o pagamento por produtividade individual para além do salário-base também ocorre há anos. Em contrapartida, as convenções coletivas de 2018 e 2019 continuaram tornando obrigatório o pagamento do salário-base aos trabalhadores a toda a categoria. Já em relação às "novas possibilidades de apropriação do trabalho" mencionadas anteriormente, uma das principais formas é o estabelecimento do fim do pagamento do tempo em que os trabalhadores estão à disposição do empregador, mas não efetivamente trabalhando, 
como o tempo in itinere, os intervalos para alimentação e de preparação para o trabalho, como o período de vestir o uniforme e os EPIs. Contudo, as convenções coletivas de trabalho dos trabalhadores rurais de Vacaria também já estabeleciam que essas horas à disposição do empregador não faziam parte do tempo de trabalho. Ou seja, da mesma forma que a questão da flexibilidade do trabalho, os termos da reforma apenas legalizaram o que já vinha ocorrendo nas práticas sociais.

Os termos da reforma que realmente significaram transformações nas práticas sociais em Vacaria foram os que afetaram os sindicatos e as instituições de Estado ligadas à Justiça do Trabalho. O estabelecimento do fim das contribuições sindicais obrigatórias (imposto sindical) foi a questão que gerou maior preocupação tanto para o STR quanto para o sindicato patronal rural, de acordo com os sindicalistas entrevistados. Diante do cenário de perda de sua principal fonte de financiamento, a opção dos sindicatos de trabalhadores rurais e patronal de Vacaria, de acordo com as decisões tomadas nas respectivas assembleias, foi pela manutenção das cláusulas adotadas anteriormente, que estabelecem a obrigatoriedade das contribuições sindicais.

As contribuições dos trabalhadores ao STR foram inicialmente regulamentadas pela cláusula 29. da CCT de 1994, segundo a qual os empregadores ficam obrigados a descontar mensalmente de seus empregados o valor de $1 \%$ do piso normativo da categoria e depositar o valor retido em uma conta indicada pelo STR (CCT, 09/02/19994, cláusula 29a). Já as contribuições sindicais dos empregadores ao sindicato patronal foram estabelecidas

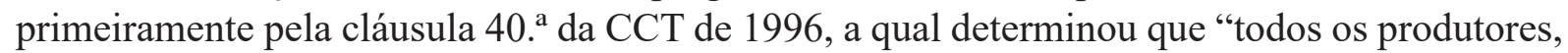
empregadores rurais e empresas que mantenham funcionários registrados devem recolher ao Sindicato dos Empregadores Rurais de Vacaria [...] a importância de R \$ 2,50 por empregado, limitando-se a um valor máximo de contribuição de $\mathrm{R} \$ 750,00$ por empresa ou propriedade" (CCT, 02/05/1996, cláusula 40. ${ }^{a}$ ).

Assim, para garantir suas fontes de financiamento, essas cláusulas foram mantidas mesmo após a aprovação da reforma. A única diferença foi na cláusula que regulamenta as contribuições dos trabalhadores, a partir da CCT de 2018, na qual um parágrafo estabelece que os trabalhadores têm um prazo de noventa dias após o início da CCT para se opor ao desconto e, nesse caso, deverão entregar uma solicitação por escrito ao STR, que deverá ser homologada no sindicato com a presença do trabalhador (CCT, 07/08/2018, cláusula 36. a, parágrafos segundo e terceiro).

Outra mudança foi em relação à participação do STR nas rescisões de contrato dos trabalhadores. Essa participação sempre foi um objetivo do STR e foi estabelecida ainda na primeira CCT, em 1994, na qual a cláusula 8. estabelecia que "Todas as rescisões de contrato de trabalho de empregados com tempo superior a 6 meses serão feitas na presença do Sindicato ou DRT [Delegacia Regional do Trabalho]" (CCT, 09/02/1994, cláusula 8). Nessa mesma cláusula, um parágrafo único garantiu que o STR disponibilizaria um funcionário especializado para revisar as rescisões dos trabalhadores de segundas-feiras às sextas-feiras em horário comercial. E, efetivamente, ao longo de todos esses anos e ainda hoje há uma funcionária que é responsável pela secretaria de assalariados rurais do STR e que desempenha essa função, conferindo as rescisões e participando das audiências na Justiça do Trabalho.

Já na CCT de 1995 foi adicionado à mesma cláusula que trata das rescisões que, no caso dos trabalhadores analfabetos, as rescisões serão acompanhadas pelo STR "a qualquer tempo após a efetivação do contrato de experiência" (CCT, 28/04/1995, cláusula 14. ${ }^{a}$ ). Em 1999, o STR conseguiu alterar a cláusula para que a presença do sindicato fosse obrigatória para rescisões de contratos a partir de cinco meses (CCT, 29/04/1999, cláusula 14. ${ }^{a}$ ). Apesar 
de essa participação ter sido desvalidada pela Reforma Trabalhista, as CCT de 2018 e 2019 mantiveram a obrigatoriedade da presença do STR nas rescisões, nos mesmos termos adotados anteriormente.

$\mathrm{Na}$ prática, contudo, apesar dos esforços do STR, de acordo com os relatos dos sindicalistas ao longo do trabalho de campo, após a aprovação da Reforma Trabalhista houve reduções de aproximadamente $27 \%$ na procura do STR pelos trabalhadores, de cerca de $30 \%$ no número de rescisões de contrato acompanhadas pelo sindicato e de $30 \%$ do número de contribuintes do STR, por opção dos próprios assalariados rurais. Essa redução corresponde à mesma diminuição no número de associados. Um dos resultados disso foi o encolhimento significativo nas receitas do sindicato. Depois disso, o STR tomou medidas como o atendimento apenas dos trabalhadores que efetivamente pagam a contribuição sindical, diferentemente da situação anterior à reforma, quando todos os trabalhadores rurais do município tinham direito a todos os serviços prestados pelo sindicato.

Além disso, para evitar a demissão de alguns de seus quadros devido à escassez de recursos, foi acordado que todos os funcionários do sindicato passarão dois anos sem nenhum reajuste salarial e que os diretores do STR passarão três anos sem nenhum reajuste salarial. Considerando esse cenário de certo afastamento dos trabalhadores do STR, passou a existir uma preocupação maior com o trabalho de base, havendo, inclusive, o projeto de aquisição de um carro pelo sindicato para que os sindicalistas pudessem se deslocar para as comunidades e propriedades do interior do município, especificamente para fazer trabalho de base, buscando contornar os efeitos nocivos da Reforma Trabalhista.

Além dos sindicatos, a dinâmica da Justiça do Trabalho também foi afetada por essa reforma. De acordo com o relato do juiz do trabalho de Vacaria (Conversa informal, novembro de 2018), houve significativa redução no número de processos abertos pelos trabalhadores após a aprovação da Reforma Trabalhista. Essa situação pode ser explicada: 1) pelo fim da obrigatoriedade da presença do STR nas rescisões de contrato dos trabalhadores, que provocou uma redução de $30 \%$ das rescisões assistidas pelo STR local, o que pode significar maior desinformação desses trabalhadores sobre seus direitos e a falta de incentivo de procurar a justiça do trabalho em caso de irregularidades, e 2) insegurança do trabalhador em abrir uma questão judicial pelo medo de perder a causa e precisar pagar os honorários de seu advogado e do advogado do empregador. Desse modo, os custos da judicialização podem ser maiores do que as perdas por irregularidades trabalhistas da parte do empregador. Assim, em linhas gerais, o que se percebe é que a Reforma Trabalhista fortaleceu um modelo de regulação privada da gestão do trabalho, em oposição ao controle público estatal que a CLT estabelecia, dando maior poder e segurança jurídica para os empregadores na definição das questões do trabalho e fragilizando os trabalhadores.

\section{CONCLUSÃO}

Considerando um contexto social marcado tanto pela consolidação do agronegócio quanto pela influência de uma tendência histórica de vulnerabilidade do trabalho rural, este trabalho teve como objetivo analisar o processo de formação dos direitos trabalhistas dos trabalhadores rurais de Vacaria ligados à cadeia produtiva da maçã, buscando compreender como a atuação de instituições como o Sindicato dos Trabalhadores Rurais e de órgãos fiscalizadores do Estado contribuíram com esse processo e quais foram os efeitos da Reforma Trabalhista de 2017 sobre o padrão local de regulação do trabalho rural construído ao longo dos anos. A instituição desse novo padrão e seu alcance nas práticas sociais é resultado de um jogo de forças 
entre vários atores. O Estado estabelece as regras gerais e as fiscaliza, mas a atuação de forças locais, como os empregadores, os sindicatos e as instituições políticas e públicas locais são os responsáveis pelo estabelecimento de formas locais de regulamentação do trabalho. Além disso, os capitais acumulados por cada um desses agentes influenciam em seu desempenho e em sua posição social e na de seus representados ao longo das disputas sociais.

No caso dos trabalhadores rurais de Vacaria, a atuação do Sindicato dos Trabalhadores Rurais tem sido fundamental para a formação e consolidação dos direitos trabalhistas e previdenciários dessa categoria. Desde antes da promulgação da Constituição de 1988, o STR luta pelo cumprimento dos direitos trabalhistas estabelecidos pelo Estatuto do Trabalhador Rural e pela ampliação e universalização dos direitos previdenciários para todos os trabalhadores rurais, o que fez com que o STR e seus dirigentes acumulassem capital político e sindical ao longo de suas trajetórias. Após a promulgação da Constituição, a luta do sindicato passou a ser pelo cumprimento da nova legislação e por melhores condições de vida e trabalho para os trabalhadores rurais. Essa luta tem sido marcada 1) pelos auxílios para a conquista de aposentadorias e por atendimento médico e odontológico, inclusive dentro do próprio sindicato, 2) por anos de insistência para a realização das convenções coletivas de trabalho, possibilitando a instituição de um padrão coletivo de salários e condições de trabalho; 3) pelas intensas negociações com o sindicato patronal por melhores salários e condições de vida e trabalho para os assalariados rurais; 4) pelo esclarecimento de dúvidas dos trabalhadores, pela participação nas rescisões de contratos, pelas cobranças de cumprimento das convenções por parte dos empregadores e pelo encaminhamento de irregularidades ao Ministério Público do Trabalho e à Justiça do Trabalho, 5) pela realização de greves e pela participação em eventos nacionais de assalariados rurais. Os principais resultados desses esforços foram o aumento dos salários nominais e reais negociados pelo STR, a ampliação da formalização do trabalho por meio do estabelecimento de sua obrigatoriedade nas convenções coletivas e o sucesso das greves realizadas por trabalhadores e sindicato, frutos do capital político acumulado pelo STR.

A atuação do Ministério Público, do Ministério Público do Trabalho e da Polícia Federal, com base nas denúncias do STR e da mídia, na fiscalização dos pomares e na autuação dos empregadores que submetiam os trabalhadores a condições de trabalho precárias também foi fundamental para a conquista de condições de trabalho mais dignas para os trabalhadores rurais do município. Do mesmo modo, foram fundamentais as condenações realizadas pela Justiça do Trabalho, muitas vezes encaminhadas e acompanhadas pelo STR. Assim, podemos dizer que a atuação conjunta do STR, do Ministério Público do Trabalho e da Justiça do Trabalho tem formado a rede de proteção dos assalariados rurais do município de Vacaria e garantido mais dignidade e melhores condições de vida e trabalho para a categoria. Por meio das denúncias aqui apresentadas, pudemos perceber que as relações de trabalho não vêm se modernizando no mesmo ritmo da modernização da cadeia produtiva da maçã e que, mesmo sendo este um setor altamente modernizado e integrado às cadeias globais de comercialização, ele teve em sua base relações e condições de trabalho degradantes. Além disso, possivelmente, esse padrão foi alterado, em grande parte, pela pressão dos agentes dos mercados consumidores internacionais, como os europeus, que exigem a consideração das normas trabalhistas e ambientais para a aquisição de bens.

Levando em conta essa dinâmica, percebe-se que a Reforma Trabalhista de 2017 procurou esvaziar a atuação dos sindicatos e da Justiça do Trabalho, que juntamente ao Ministério Público do Trabalho compõem os três elos da rede de proteção dos trabalhadores rurais de Vacaria. Como as relações trabalhistas praticadas na cadeia produtiva da maçã já adotavam o modelo de trabalho flexível estabelecido pela reforma, influência do período de 
reestruturação produtiva, os principais efeitos da reforma se deram sobre os sindicatos e a Justiça do Trabalho. Contudo, diante da tentativa de esvaziamento da ação sindical por meio do fim das contribuições sindicais obrigatórias e do fim da obrigatoriedade da presença dos sindicatos nas rescisões de contrato, o STR e o sindicato patronal de Vacaria optaram pela manutenção, nas convenções coletivas de trabalho, das cláusulas que regulamentam esses pontos nos mesmos termos utilizados antes da aprovação da nova legislação, em uma clara tentativa de autoproteção, à revelia das alterações estabelecidas pelo governo. Apesar disso, no caso do STR de Vacaria, houve redução das contribuições sindicais e da procura do sindicato para realizar as rescisões de contrato. Com isso, desde a aprovação da reforma, os sindicalistas do STR vêm dando sinais de que tentam reformular suas ações e buscam maior aproximação de suas bases, o que pode levar a avanços para a categoria na luta por uma posição social melhor. Assim, a aprovação da reforma não deixou de significar uma desregulamentação do padrão social de trabalho instituído e de tornar ainda maiores os desafios historicamente enfrentados pelos trabalhadores rurais e brasileiros em geral.

\section{REFERÊNCIAS}

ADASCALITEI, Dragos, PIGNATTI MORANO, Clemente. Drivers and effects of labour market reforms: evidence from a novel policy compendium. IZA J Labor Policy, v. 5, n. 15, 2016.

ALVES, Francisco. Por que morrem os cortadores de cana? Saúde e Sociedade, São Paulo, v. 15, n. 3, 2006.

ANDERSON, Perry. Balanço do neoliberalismo. In: GENTILI, Pablo; SADER, Emir. (Orgs.). Pós-neoliberalismo: as políticas sociais e o Estado democrático. São Paulo: Paz e Terra, 1996.

ANTUNES, R. Os Sentidos do Trabalho: ensaio sobre a afirmação e a negação do trabalho. São Paulo: Boitempo, 2009.

BARROS, Verônica Altef. As comissões de conciliação prévia e o acesso ao judiciário. Revista Jurídica UNIJUS, v. 4, n. 1, 2001.

BEZERRA, Juscelino Eudâmidas; ELIAS, Denise. Difusão do trabalho agrícola formal no Brasil e sua dinâmica multiescalar. Investigaciones geográficas, Alicante, n. 76, 2011.

BIAVASCHI, Magda Barros; TEIXEIRA, Marilane Oliveira. A reforma trabalhista brasileira na dinâmica da economia e seus impactos na regulação pública do trabalho: em diálogo comparado com a reforma em andamento na Argentina. Século XXI, Revista de Ciências Sociais, Santa Maria, v. 8, n. 2, 2018.

BORGES, Maria Neli Ferreira. História de Vacaria: evolução urbana e formação dos bairros. Caxias do Sul, RS: EDUCS, 2001.

BOURDIEU, P. O poder simbólico. Rio de Janeiro: Bertrand Brasil, 1989.

BRASIL. Constituição da República Federativa do Brasil de 1988. Brasília, DF: Senado Federal: Edição administrativa do Senado Federal, 2016.

. Lei n. ${ }^{\circ}$ 4.214, de 2 de março de 1963. Dispõe sôbre o "Estatuto do Trabalhador Rural". Diário Oficial da União, Poder Executivo, Brasília, 1963.

Lei n. ${ }^{\circ}$ 13.429, de 31 de março de 2017. Altera dispositivos da Lei n. ${ }^{\circ} 6.019$, de 3 de janeiro de 1974, que dispõe sobre o trabalho temporário nas empresas urbanas e dá outras 
providências; e dispõe sobre as relações de trabalho na empresa de prestação de serviços a terceiros. Diário Oficial da União, Poder Executivo, Brasília, 2017a.

Lei n. ${ }^{\circ}$ 13.467, de 13 de julho de 2017. Altera a Consolidação das Leis do Trabalho (CLT), aprovada pelo Decreto-Lei ${ }^{0} 5.452$, de $1^{\circ}$ de maio de 1943 , e as Leis $n^{\circ} 6.019$, de 3 de janeiro de 1974, 8.036, de 11 de maio de 1990, e 8.212, de 24 de julho de 1991, a fim de adequar a legislação às novas relações de trabalho. Diário Oficial da União, Poder Executivo, Brasília, $2017 b$.

Ministério do Trabalho. Cadastro Geral de Empregados e Desempregados (Caged). Tabela 12: Saldo do emprego formal celetista por município e setor de atividade econômica. 2019. Disponível em: http://pdet.mte.gov.br/caged/caged-2019/cagedjaneiro-2019. Acesso em: 8 fev.2020.

CASTEL, R. As metamorfoses da questão social: uma crônica do salário. Petrópolis: Vozes, 1998.

CONVENÇÕES COLETIVAS DE TRABALHO DA CATEGORIA TRABALHADOR RURAL. 1994-2019. Disponibilizadas pelo Sindicato dos Trabalhadores Rurais de Vacaria-RS.

CORREIO VACARIENSE. Edições 397 (10/05/1983)-1.681 (14/05/2003). Acervo impresso disponível na Biblioteca Pública Municipal de Vacaria. Vacaria-RS.

DELGADO, Guilherme; SCHWAERZER, Helmut. Evolução histórico-legal e forma de financiamento da previdência rural no Brasil. In: DELGADO, Guilherme; CARDOSO JR., José Celso. Universalização de direitos sociais no Brasil: a previdência rural nos anos 90 . Brasília: Ipea, 2000.

DIEESE - DEPARTAMENTO INTERSINDICAL DE ESTATÍSTICA E ESTUDOS SOCIOECONÔMICOS. O mercado de trabalho assalariado rural brasileiro. Estudos e Pesquisas. n. 74, 2014.

Salário mínimo. Disponível em: https://www.dieese.org.br/analisecestabasica/ salarioMinimo.html. s/d. Acesso em: 20 maio 2018.

DUARTE, L. Denúncias rebatidas em Vacaria. Jornal Pioneiro, Caxias do Sul, 11/05/2002, p. 6 .

DUPAS, Gilberto. Atores e poderes na nova ordem global: assimetrias, instabilidades e imperativos de legitimação. São Paulo: Ed. Unesp, 2005.

ELIAS, Denise. Globalização e fragmentação do espaço agrícola do Brasil. Scripta Nova Revista Electrónica de Geografía y Ciencias Sociales, Barcelona, v. X, n. 218, 2006.

ESTATUTO DO TRABALHADOR RURAL. In: LAMARÃO, Sérgio; MEDEIROS, Leonilde Sérvolo de. Dicionário Histórico-Biográfico Brasileiro: pós-1930. Rio de Janeiro: CPDOC, 2001.

GALVÃO, Andréia; TEIXEIRA, Marilane O. Flexibilização na lei e na prática: o impacto da reforma trabalhista sobre o movimento sindical. In: KREIN, José Dari Denis; GIMENEZ, Maracci; SANTOS, Anselmo Luis dos. (Org.). Dimensões críticas da reforma trabalhista no Brasil. Campinas: Curt Nimuendajú, 2018.

HEREDIA, Beatriz; PALMEIRA, Moacir; LEITE, Sérgio. Sociedade e economia do "agronegócio" no Brasil. Revista Brasileira de Ciências Sociais, v. 25, n. 74, 2010. 
IBGE - Instituto Brasileiro de Geografia e Estatística. Censo Agropecuário 2006. Agricultura Familiar: primeiros resultados - Brasil, grandes regiões. Rio de Janeiro: IBGE, 2006.

Censo Agropecuário 2017. Disponível em: https://sidra.ibge.gov.br/pesquisa/censoagropecuario/censo-agropecuario-2017. Acesso em 14 nov. 2019.

Pesquisa nacional por amostra de domicílios: síntese de indicadores - 2015. Rio de Janeiro: IBGE, 2016.

KREIN,JoséDari.Neoliberalismoe trabalho.In:CATTANI,AntonioDavid;HOLZMANNORGS Lorena. (Org.). Dicionário de trabalho e tecnologia. Porto Alegre: Zouk, 2011.

KREIN, José Dari. O desmonte dos direitos, as novas configurações do trabalho e o esvaziamento da ação coletiva: consequências da reforma trabalhista. Tempo Social - Revista de Sociologia da USP, São Paulo, v. 30, n. 1, 2018.

LAMARÃO, Sérgio.; MEDEIROS, Leonilde Sérvolo de. Verbete ESTATUTO DO TRABALHADOR RURAL. In: Dicionários Histórico-Biográfico Brasileiro - Pós 1930. Rio de Janeiro: CPDOC, 2001.

LERMEN, Nadine Gerhardt. A vida por trás dos galhos das macieiras: (o)posições sociais e representação classista na cadeia produtiva da maçã em Vacaria-RS. 2020. Dissertação (Mestrado em Ciências Sociais). Universidade Federal de Santa Maria, Santa Maria-RS, 2020.

LÚCIO, Clemente Ganz. O novo mundo do trabalho é flexível, precário e inseguro, Carta Social e do Trabalho, n. 38, 2019.

MACIEL, Lidiane Maria. O sentido de melhorar de vida: arranjos familiares na dinâmica das migrações rurais-urbanas em São Carlos-SP. Dissertação (Mestrado em Sociologia) Universidade Estadual de Campinas, Campinas, 2012.

MEDEIROS, Leonilde Sérvolo de. Agricultura familiar no Brasil: aspectos da formação de uma categoria política. In: MANZANAL, Mabel; NEIMAN, Guillermo (Org.). Las agriculturas familiares del Mercosur: trayectorias, amenazas y desafíos. Buenos Aires: CICCUS, 2010.

MEDEIROS, Leonilde Sérvolo de. História dos movimentos sociais no campo. Rio de Janeiro: Fase, 1989.

MENDONÇA, Maria Luísa Rocha Ferreira de. Modo capitalista de produção e agricultura: a construção do conceito de agronegócio. Tese (Doutorado em Geografia Humana) - Universidade de São Paulo, São Paulo, 2013.

MENEZES, Marilda Aparecida de. Migrações: uma experiência histórica do campesinato do Nordeste. In: GODOI, Emilia Pietrafesa de.; MENEZES, Marilda Aparecida de.; MARIN, Rosa Acevedo (Org.). Diversidade do campesinato: expressões e categorias. São Paulo: Ed. Unesp, 2009. v. II - Estratégias de reprodução social. p. 270-288.

NOVAES, Regina Reyes. De corpo e alma: catolicismo, classes sociais e conflitos no campo. Rio de Janeiro: Graphia, 1997.

PALMEIRA, Moacir. A diversidade da luta no campo: luta camponesa e diferenciação do campesinato. In: PAIVA, V. (Org.). Igreja e questão agrária. São Paulo: Loyola, 1985.

PALMEIRA, Moacir. Modernização, Estado e Questão Agrária. Estudos Avançados. São Paulo, 1999. 
PEREIRA, Giovana Gonçalves. Entre o partir e o chegar: os trabalhadores rurais migrantes em Matão/SP. Dissertação (Mestrado em Demografia) - Universidade Estadual de Campinas, Campinas, 2015.

PEREIRA, Giovana Gonçalves. Migrações e agronegócio: espaços na citricultura paulista. Campinas-SP. Tese (Doutorado em Demografia) - Universidade Estadual de Campinas, Campinas, 2019.

PICOLOTTO, Everton Lazzaretti. As mãos que alimentam a nação: agricultura familiar, sindicalismo e política. Tese (Doutorado em Ciências Sociais) - Universidade Federal Rural do Rio de Janeiro, Rio de Janeiro, 2011.

PICOLOTTO, Everton Lazzaretti. Pluralidade sindical no campo? Agricultores familiares e assalariados rurais em um cenário de disputas. Lua Nova, São Paulo, v. 104, 2018.

PINOTTI, Adhemar. Só para lembrar: Vacaria em fotos. Caxias do Sul, RS: Lorigraf, 2011.

RECH, Samara; CARIO, Silvio A. Ferraz; AUGUSTO, Cleiciele Albuquerque. Avaliação conjuntural da produção e comercialização da maçã em Santa Catarina e no Rio Grande do Sul: aspectos comparativos. Indicadores Econômicos FEE, Porto Alegre, v. 42, n. 1, 2014.

RITZEL, L.; PEDROSO, E. As mãos da colheita da maçã. Zero Hora, Porto Alegre, 14 mar. 2004. Especial, p. 34-35.

SEYFERTH, Giralda. Os alemães no Brasil: uma síntese. In: BRASIL: migrações internacionais e identidades. Campinas: Comciência, 2000.

SILVA, José Graziano da. A modernização dolorosa: estrutura agrária, fronteira agrícola e trabalhadores rurais no Brasil. Rio de Janeiro: Zahar, 1982.

SILVA, Maria Aparecida de Moraes; MELO, B. M. As distintas faces da intermediação entre capital e trabalho rural no Brasil. Eutopía: Revista de Desarrollo Económico Territorial, v. 9, 2016.

SINDICATO DOS TRABALHADORES RURAIS DE VACARIA E MUITOS CAPÕES. Revista comemorativa dos 50 anos do Sindicato dos Trabalhadores Rurais. Vacaria-RS, 2015.

SOUZA, Jessé. A classe média no espelho: sua história, seus sonhos e ilusões, sua realidade. Rio de Janeiro: Estação Brasil, 2018.

TREZZI, H. Trabalho semiescravo é denunciado. Jornal Pioneiro, Caxias do Sul, 10/05/2002, p. 6 .

VALADARES, Alexandre.; GALIZA, Marcelo.; OLIVEIRA, Tiago. A reforma trabalhista e o trabalho no campo. Mercado de Trabalho, n. 63, 2017. 